\title{
Amino Acid Sequence Determination of Nine Tryptic Peptides from lle Chain of Ricin $\mathrm{D}^{\dagger}$
}

\author{
Shinji Yoshitake, Gunki Funatsu and Masaru Funatsu \\ Laboratory of Biochemistry, Faculty of Agriculture, \\ Kyushu University, Fukuoka 812, Japan \\ Received January 30, 1978
}

\begin{abstract}
Amino acid sequences of nine tryptic peptides derived from performic acid oxidized Ile-chain or cyanogen bromide fragments of the protein were determined mainly by the modified Edman procedure. Thus, 177 residues $(67 \%)$ out of a total of 265 amino acid residues of the polypeptide chain were sequenced in the present study.
\end{abstract}

In the previous report, ${ }^{1}$ we have described the isolation of twenty tryptic peptides from performic acid oxidized Ile-chain of ricin D and amino acid sequences of some peptides. In this publication, we report the determination of amino acid sequence of nine relatively large tryptic peptides isolated from either performic acid oxidized Ile-chain or cyanogen bromide fragments of the protein.

\section{MATERIALS AND METHODS}

Materials. Chymotrypsin was purchased from Nutritional Biochemical Corp. Pepsin was the product of Sigma Chemical Co. Other chemicals are of analytical grade.

Tryptic peptides. Tryptic peptides DaT10, DaT12, DaT13, DaT18, DaT19, and DaT20 were prepared from performic acid oxidized Ile-chain as previously described. $^{\text {l }}$ DaT22 was isolated from tryptic digest of cyanogen bromide fragment $\mathrm{CB} I$ of Ile-chain. ${ }^{2}$ Peptides DaT16 and CB II-TP were isolated from cyanogen bromide fragment CB II of Ile-chain. Peptide DaT23 was obtained from tryptic digest of maleylated oxidized Ile-chain by successive column chromatography on Sephadex G25 $(1.9 \times 190 \mathrm{~cm}, 5 \%$ acetic acid as elution solvent), Dowex $1 \times 2(0.9 \times$ $87 \mathrm{~cm}$ ), Sephadex $\mathrm{G} 25$ in $30 \%$ formic acid, and Sephadex $\mathrm{G} 50$ in $40 \%$ formic acid.

Enzymatic methods. Tryptic peptides were digested with chymotrypsin in deionized water at $37^{\circ} \mathrm{C}$ for $3 \mathrm{hr}$. $\mathrm{pH}$ of the solution was adjusted to 8.0 with $\mathrm{NH}_{4} \mathrm{OH}$ beforehand. Peptides were also hydrolyzed with pepsin in $5 \%$ formic acid for $6 \mathrm{hr}$ at $37^{\circ} \mathrm{C}$. After

${ }^{\dagger}$ Biochemical Studies on Ricin. Part XXI. For Part XX, see Agric. Biol. Chem., 42, 1253 (1978). digestion, the mixture was evaporated to dryness. The amount of enzyme was generally $10 \%$ by weight of the peptides to be hydrolyzed.

Chromatography. Ion-exchange chromatography on Dowex $1 \times 2$ and paper chromatography were performed using solvent systems described previously. ${ }^{1)}$

Amino acid analyses. Peptide samples were hydrolyzed with $5.7 \mathrm{~N}$ hydrochloric acid containing $0.05 \% 2$-mercaptoethanol in a evacuated sealed tube at $105^{\circ} \mathrm{C}$ for $24 \mathrm{hr}^{3)}$ Automated amino acid analyses were performed with a JEOL JLC-6AH amino acid analyzer according to the method of Spackman et al ${ }^{4}$ )

Other methods. Tryptophan residue in a peptide was detected by staining with p-dimethylaminobenzaldehyde. ${ }^{5)}$ Hydrolysis of peptide with $4 \mathrm{~N}$ methanesulfonic acid containing $0.2 \% \quad 3$-(2-aminoethyl)indol, ${ }^{\circ}$ followed by amino acid analysis, was also employed for tryptophan determination.

Manual Edman degradation. Edman degradation procedure employed was essentially the same as that of Iwanaga and Samejima ${ }^{7)}$ with some modification of Peterson et al. ${ }^{8)}$ The peptide (up to 700 nmole) was dissolved in $200 \mu \mathrm{l}$ of $0.4 \mathrm{M}$ dimethylallylaminetrifluoroacetate buffer, $\mathrm{pH} 9.7$ in $60 \%$ aqueous 1propanol. $10 \mu \mathrm{l}$ of phenylisothiocyanate was added, and the tube was flushed with nitrogen. The content was mixed and incubated for $30 \mathrm{~min}$ at $50^{\circ} \mathrm{C}$. The reaction mixture was extracted twice with $1 \mathrm{ml}$ of benzene. The benzene phase was discarded after centrifugation, the aqueous phase was initially dried under gentle stream of nitrogen with warming, or lyophilized, and then further dried under high vacuum (less than $0.005 \mathrm{mmHg}$ ) for $30 \mathrm{~min}$ at $50^{\circ} \mathrm{C}$. Cleavage was performed by dissolving the peptides in $200 \mu 1$ of anhydroous trifluoroacetic acid (TFA) and the tube was heated at $50^{\circ} \mathrm{C}$ for $10 \mathrm{~min}$ under nitrogen. TFA was removed 
by nitrogen so that the peptide would spread into thin film at the bottom of the tube. The thiazolinone derivatives were extracted once with $1 \mathrm{ml}$ of ethylenedichloride. After removal of the solvent, the residual peptide was dried and then dissolved again in small amount of TFA. TFA was evaporated immediately and extraction with ethylenedichloride was repeated once. Conversion of thiazolinone derivatives into PTH-amino acids and quantitation of PTH-'s were performed as described by Iwanaga and Samejima. ${ }^{7}$ PTH-amino acids were identified by thin-layer chromatography on a Silica gel $\mathrm{GF}_{254}$ plate using solvent system VM ( $n$-heptane: ethylenedichloride: propionic acid $=45: 25: 30, \mathrm{v} / \mathrm{v}$ ) ${ }^{9)}$ or system II (chloroform: methanol $=9: 1, \mathrm{v} / \mathrm{v})$. Ninhydrin staining of PTHamino acids was employed to promote more precise identification. After chromatographic development, the thin-layer plate was sprayed with $0.3 \%$ ninhydrin (ethanol: acetic acid: collidine $=87: 10: 3, \mathrm{v} / \mathrm{v}$ ) and heated at $100^{\circ} \mathrm{C}$ for 10 to $15 \mathrm{~min}$ with occasional observation of color development. All PTH-'s with exception of PTH-proline showed a characteristic color. ${ }^{10)}$ Carboxyl terminal arginine residue of tryptic peptides was identified and quantitated as free arginine residue on an amino acid analyzer. After definite steps of Edman degradation, the residual material in a tube was directly applied to a short column of analyzer.

Manual solid-phase Edman degradation. Triethylenetetramine sequencing resin was synthesized as described by Horn and Laursen. ${ }^{11}$ Peptides were attached via their carboxyl terminal homoserine lactone to the resin, ${ }^{11}$ Edman degradation of resin-attached peptides was performed according to the procedure of Previero et al. ${ }^{12)}$ with minor modifications. Degradation was carried out in a glass-stoppered centrifuge tube. After coupling with phenylisothiocyanate, the resin was washed extensively with dimethylformamide, benzene and finally with acetone. Then the resin was dried under high vacuum for $20 \mathrm{~min}$ at $50^{\circ} \mathrm{C}$. Cleavage was performed by suspending the resin in TFA. Thiazolinone derivatives were extracted with acetone. Quantitation and identification of PTH-derivatives were performed as described above.

\section{RESULTS}

\section{Amino acid sequences of tryptic peptides}

Peptide DaT 10. Twenty steps of Edman degradation established the complete amino acid sequence of the peptide DaT 10 (Table I). To confirm the sequence of this peptide, it was digested with pepsin and the resulting peptides were purified by combination of
Table I. Amino Acid Sequences of Tryptic Peptides

The amino acids cleaved by the direct Edman degradation are indicated by arrows $(\rightarrow)$; Edman degradation on subfragments $(\rightarrow)$; Residues deduced from amino acid composition $(-\rightarrow)$.

\begin{tabular}{lc}
\hline Peptide & \multicolumn{1}{c}{ Amino acid sequence } \\
\hline DaT-10 & $\stackrel{\text { Leu-Ser-Thr-Ala-Ile-Gln-Glu-Ser- }}{\longrightarrow}$ \\
& $\stackrel{\text { Asn-Gln-Gly-Ala-Phe-Ala-Ser-Pro- }}{\longrightarrow}-\stackrel{\longrightarrow}{\longrightarrow}$ \\
& $\stackrel{\text { Ile-Gln-Leu-Gln-Arg }}{\longrightarrow}$
\end{tabular}

DaT-12 His-Glu-Ile-Pro-Val-Leu-Pro-Asn-Arg

DaT-13 Leu-Glu-Gin-Leu-Ala-Gly-Asn-LeuArg

DaT-16 Ser-Ala-Pro-Asp-Pro-Ser-Val-IleThr-Leu-Glu-Asn-Ser-Trp-Gly-Arg

DaT-18 Ala-Gly-Asn-Ser-Ala-Tyr-Phe-Phe$\overrightarrow{\text { His }}-\overrightarrow{P r o}-\overrightarrow{A s p}-\overrightarrow{A s n}-\underline{G I n}-\underline{G l u}-\overrightarrow{A s p}-\overrightarrow{A l a}-$ Glu-Ala-Ile-Thr-His-Leu-Phe-Thr$\overrightarrow{\mathrm{Asp}}-\overrightarrow{\mathrm{VaI}}-\overrightarrow{\mathrm{Gln}}-\overrightarrow{\mathrm{Asn}}-\mathrm{Arg}$

DaT-19 Ser-Phe-Ile-Ile-CySO ${ }_{3} \mathrm{H}-\mathrm{Ile}-\mathrm{Gln}-$ $\mathrm{MetO}_{2}-$ Ile-Ser-Glu-Ala-Ala-Arg

DaT-20 Glu-Asn-Ile-Glu-Leu-Gly-Asn-Gly-

$\stackrel{\text { Pro-Leu-Glu-Glu-Ala-Ile-Ser-Ala- }}{\longrightarrow}$

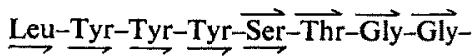

$\overrightarrow{T h r}-\overrightarrow{G l n}-\overrightarrow{L e u}-\overrightarrow{P r o}-T h r-\overline{L e u}-\overrightarrow{A l a}-\overrightarrow{A r g}$

DaT-22 Phe-Ile-Leu-Val-Glu-Leu-Gin-Asn-

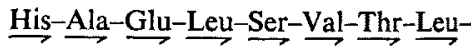

$\stackrel{\text { Ala-Leu-Ser-Val-Thr-Asn-Ala-Tyr- }}{\longrightarrow}$

$\overrightarrow{\mathrm{Val}}-\overrightarrow{\mathrm{Val}}-\overrightarrow{\mathrm{Gly}}-\overrightarrow{\mathrm{Tyr}}-\mathrm{Arg}$

DaT-23 $\overrightarrow{\text { Phe }}-\overrightarrow{\mathrm{Ser}}-\overrightarrow{\mathrm{Val}}-\overrightarrow{\mathrm{Tyr}}-\overrightarrow{\mathrm{Asp}}-\overrightarrow{\mathrm{Val}}-\overrightarrow{\mathrm{Ser}}-\overrightarrow{\mathrm{Ile}}-\overrightarrow{\mathrm{Leu}}-$

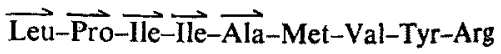

column chromatography on Dowex $1 \times 2$ and paper chromatography (Fig. 1). Examining the amino acid composition of these fragments (Table II) and peptic specificity, these were unambiguously aligned in the sequence of $\mathrm{D} \alpha \mathrm{T} 10$.

Peptides $D \alpha T 12$ and $D \alpha T 13 . \quad$ Eight steps of Edman degradation and amino acid ana- 


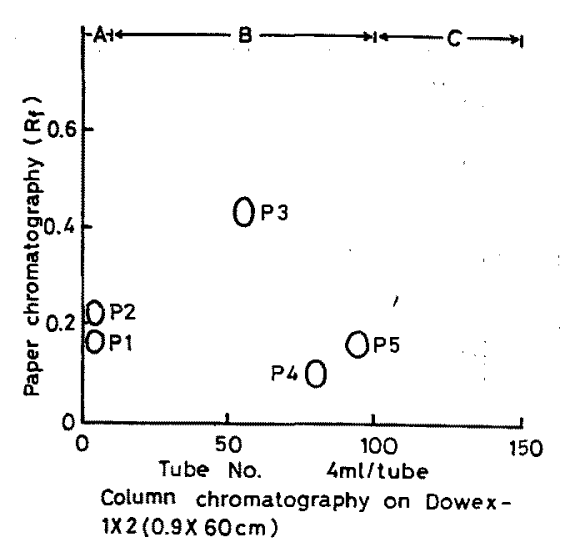

Fig. 1. Separation of Peptic Peptides Derived from DaT-10.

Elution solvent system for Dowex $1 \times 2$ (Eight chambered polygradienter was used). A: $2 \%$ pyridineacetate, $\mathrm{pH} 8.3$;
B: Chambers $1,2,3,4,2 \%$ pyridine-acetate, $\mathrm{pH} 7.3$
Chamber
$5,0.02 \mathrm{~N}$ acetic acid
Chamber
$6,0.2 \mathrm{~N}$ acetic acid
Chamber
$7,0.35 \mathrm{~N}$ acetic acid
Chamber
$8,0.5 \mathrm{~N}$ acetic acid;
C: Chamber
$1,0.5 \mathrm{~N}$ acetic acid
Chamber
$2,10 \%$ acetic acid
Chamber
$3,30 \%$ acetic acid

TABle II. AMINo ACID CoMposition of Peptic Peptides Derived from D $\alpha \mathrm{T}-10$

\begin{tabular}{|c|c|c|}
\hline Peptide & $\begin{array}{l}\text { Position } \\
\text { in the } \\
\text { sequence }\end{array}$ & Amino acid composition \\
\hline P1 & $19 \sim 21$ & $\operatorname{Arg}_{1.0(1)} \operatorname{Glu}_{1.2(1)} \operatorname{Leu}_{1.1(1)}$ \\
\hline P2 & $14 \sim 21$ & $\begin{array}{l}\text { Arg }_{1.0(1)} \operatorname{Ser}_{0.8(1)} \text { Glu }_{1.8(2)} \operatorname{Pro}_{0.8(1)} \\
\text { Ala }_{0.8(1)} \operatorname{Lle}_{0.8(1)} \operatorname{Leu}_{0.8(1)}\end{array}$ \\
\hline P3 & $1 \sim 4$ & $\mathrm{Thr}_{0.8(1)} \operatorname{Ser}_{1.0(1)} \mathrm{Ala}_{1.0(1)} \mathrm{Leu}_{0 . \theta(1)}$ \\
\hline P4 & $5 \sim 12$ & $\begin{array}{l}\mathrm{Asp}_{1.0(1)} \mathrm{Ser}_{1.2(1)} \mathrm{Glu}_{2.6(3)} \mathrm{Gly}_{1.2(1)} \\
\mathrm{Ala}_{1.2(1)} \mathrm{Ile}_{0.8(1)}\end{array}$ \\
\hline P5 & $5 \sim 13$ & $\begin{array}{l}\text { Asp }_{1,0(1)} \operatorname{Ser}_{1.0(1)} \mathrm{Glu}_{3.3(3)} \mathrm{Gly}_{1.1(1)} \\
\mathrm{Ala}_{1.4(1)} \mathrm{Ile}_{1.0(1)} \mathrm{Phe}_{1,0(1)}\end{array}$ \\
\hline
\end{tabular}

lyses of the remaining materials completed the amino acid sequence determinations of these peptides (Table I).

Peptide DaT 16. The amino acid sequence of the peptide, which is the unique tryptophan containing peptide isolated from Ile-chain, was determined by fifteen consecutive steps of Edman degradation. PTH-amino acids obtained at 13 th and 14 th steps were not cor-

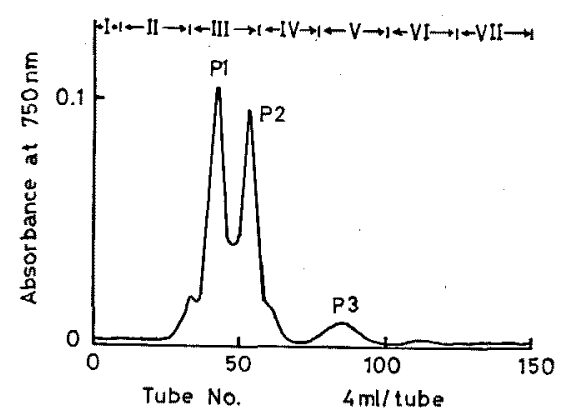

Frg. 2. Elution Profile of Peptic Peptides Derived from DaT -16 on a Column $(0.6 \times 64 \mathrm{~cm})$ of Dowex $1 \times 2$.

Buffer system (see ref. 1).

TAble III. Amino Acid Composition of Peptic Peptides from DaT-16

\begin{tabular}{|c|c|c|}
\hline $\begin{array}{c}\text { Peptide } \\
(\text { DaT-16-) }\end{array}$ & $\begin{array}{l}\text { Position } \\
\text { in the } \\
\text { sequence }\end{array}$ & Amino acid composition \\
\hline P1-1 & $9 \sim 10$ & Thr $_{0.9(1)}$ Leu $_{1.0(1)}$ \\
\hline P2 & $10 \sim 16$ & $\begin{array}{l}\text { Arg }_{0.8(1)} \text { Asp }_{1.0(1)} \operatorname{Ser}_{1.4(1)} \\
\text { Glu }_{1.0(1)} \text { Gly }_{1.2(1)} \operatorname{Leu}_{0.8(1)} \operatorname{Trp}_{(1)}\end{array}$ \\
\hline P3-1 & $1 \sim 7$ & $\begin{array}{l}\text { Asp }_{1.2(1)} \operatorname{Ser}_{1.8(2)} \operatorname{Pro}_{1.8(2)} \text { Ala }_{1.1(1)} \\
\text { Val }_{1.0(1)}\end{array}$ \\
\hline P3-2 & $1 \sim 9$ & $\begin{array}{l}\text { Asp }_{1.1(1)} \mathrm{Thr}_{0.8(1)} \mathrm{Ser}_{1.8(2)} \operatorname{Pro}_{1.8(2)} \\
\text { Ala }_{1.0(1)} \mathrm{Val}_{0.8(1)} \operatorname{Ile}_{0.7(1)}\end{array}$ \\
\hline
\end{tabular}

rectly identified. Peptic digestion of the peptide D $\alpha \mathrm{T} 16$ released 4 fragments, which were separated by ion-exchange and paper chromatographies (Fig. 2 and Table III). Chymotryptic digestion of D $\alpha \mathrm{T} 16$ liberated carboxyl terminal peptide Gly-Arg. From these results, amino acid residues at 13 th and 14th should be Ser-Trp. The amino acid sequence of DaT 16 was shown in Table I.

Peptide DaT 18. Twentyeight steps of Edman degradation established almost all of the sequence of the peptide. Chymotryptic digestion of the peptide gave three peptides, which were purified by Dowex $1 \times 2$ column chromatography (Fig. 3 and Table IV). D $\alpha \mathrm{T} 18-\mathrm{Cl}$, which was the carboxyl terminal peptide, was subjected to Edman degradation, and the amino acid sequence was determined to be: Thr-Asp-Val-Gln-Asn-Arg. Table I shows the complete sequence of $\mathrm{D} \alpha \mathrm{T}$ 18. 


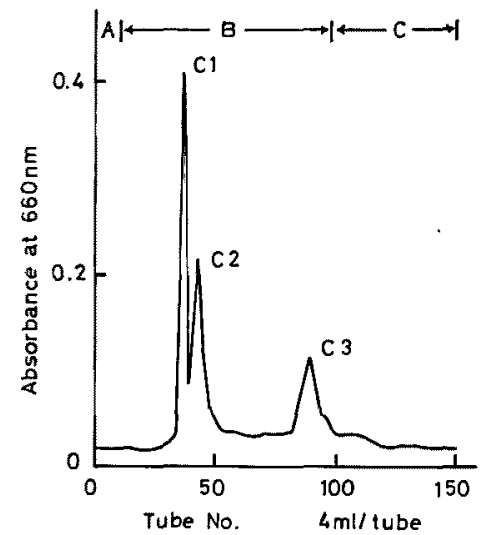

FIG. 3. Elution Profile of the Chymotryptic Peptides Derived from D $\alpha \mathrm{T} 18$ on a Column $(0.6 \times 64 \mathrm{~cm})$ of Dowex $1 \times 2$.

Buffer system (see legend on Fig. 1)

Table IV. Amino Acid Composition of Chymotryptic Peptides Derived FROM $\mathrm{D} \alpha \mathrm{T}-18$

\begin{tabular}{ccl}
$\begin{array}{c}\text { Peptide } \\
(\mathrm{D} \alpha \mathrm{T}-18-)\end{array}$ & $\begin{array}{c}\text { Position } \\
\text { in the } \\
\text { sequence }\end{array}$ & \multicolumn{1}{c}{ Amino acid composition } \\
\hline $\mathrm{C}-1$ & $24 \sim 29$ & $\begin{array}{l}\mathrm{Arg}_{0.8(1)} \mathrm{Asp}_{2.1(2)} \mathrm{Thr}_{1.0(1)} \\
\mathrm{Glu}_{1.0(1)} \mathrm{Val}_{0.8(1)}\end{array}$ \\
$\mathrm{C}-2$ & $1 \sim 6$ & $\begin{array}{l}\mathrm{Asp}_{1.2(1)} \mathrm{Ser}_{0.8(1)} \mathrm{Gly}_{1.1(1)} \mathrm{Ala}_{2.0(2)} \\
\mathrm{Tyr}_{0.8(1)}\end{array}$ \\
$\mathrm{C}-3$ & $7 \sim 23$ & $\begin{array}{l}\mathrm{His}_{1.7(2)} \mathrm{Asp}_{3.1(3)} \mathrm{Thr}_{1.0(1)} \\
\mathrm{Glu}_{3.2(3)} \mathrm{Pro}_{1.0(1)} \mathrm{Ala}_{2.1(2)} \mathrm{Ile}_{1.0(1)} \\
\mathrm{Leu}_{1.0(1)} \mathrm{Phe}_{2.8(3)}\end{array}$ \\
\hline
\end{tabular}

Peptide DaT 19. Thirteen steps of Edman degradation unambiguously established the amino acid sequence of the peptide (Table I). PTH-Methionine sulfone, of which $R f$ value was 0.10 in solvent VM, migrated between PTH-Ser and PTH-Gln.

Peptide DaT 20. Twentyone amino acid sequence from $\mathrm{N}$-terminus of the peptide was determined to be: Glu-Asn-lle-Glu-LeuGly-Asn-Gly-Pro-Leu-Glu-Glu-Ala-Ile-Ser -Ala-Leu-Tyr-Tyr-Tyr-Ser-. Rapid decrease in yield of PTH-Asn at 7th step made further degradation difficult. The peptide was digested with chymotrypsin and the resulting fragments were purified by chromatography on Dowex $1 \times 2$ (Fig. 4 and Table V). Eleven steps of Edman degradation established the

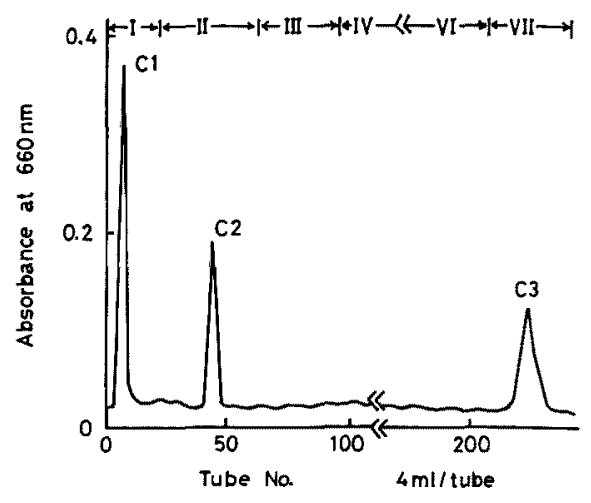

Fig. 4. Elution Profile of the Chymotryptic Peptides Derived from $D \alpha T 20$ on a Column $(1.0 \times 48 \mathrm{~cm})$ of Dowex $1 \times 2$.

Buffer system (see ref. 1).

Table V. Amino Acid Composition of Chymotryptic Peptides Dertved FROM DaT-20

\begin{tabular}{|c|c|c|}
\hline $\begin{array}{c}\text { Peptide } \\
\text { (DaT-20-) }\end{array}$ & $\begin{array}{l}\text { Position } \\
\text { in the } \\
\text { sequence }\end{array}$ & Amino acid composition \\
\hline $\mathrm{C}-1$ & $21 \sim 32$ & $\begin{array}{l}\mathrm{Arg}_{1.3(1)} \operatorname{Thr}_{2.8(3)} \mathrm{Ser}_{1.1(1)} \\
\mathrm{Glu}_{1.2(1)} \operatorname{Pro}_{1.0(1)} \mathrm{Gly}_{2.2(2)} \\
\mathrm{Ala}_{1.2(2)} \mathrm{Leu}_{2.3(2)}\end{array}$ \\
\hline $\mathrm{C}-2$ & $19 \sim 32$ & $\begin{array}{l}\text { Arg }_{1.3(1)} \operatorname{Thr}_{2.7(3)} \text { Ser }_{1.2(1)} \\
\text { Glu }_{1.2(1)} \operatorname{Pro}_{1.4(1)} \text { Gly }_{2.4(2)} \\
\text { Ala }_{1.1(1)} \operatorname{Leu}_{2.3(2)} \operatorname{Tyr}_{2.0(2)}\end{array}$ \\
\hline$C-3$ & $1 \sim 18$ & $\begin{array}{l}\text { Asp }_{2.2(2)} \operatorname{Ser}_{0.8(1)} \mathrm{Glu}_{3.7(4)} \\
\text { Pro }_{0.9(1)} \mathrm{Gly}_{2.1(2)} \mathrm{Ala}_{2.0(2)} \\
\text { Ile }_{1.9(2)} \mathrm{Leu}_{3.0(3)} \mathrm{Tyr}_{0.8(1)}\end{array}$ \\
\hline
\end{tabular}

amino acid sequence of $\mathrm{D} \alpha \mathrm{T} 20-\mathrm{Cl}$, to be: Ser-Thr-Gly-Gly-Thr-Gln-Leu-Pro-Thr-Leu -Ala-Arg. Table I summarises the complete amino acid sequence of DaT 20.

Peptide DaT 22. Twentyeight steps of Edman degradation completed the amino acid sequence determination of the peptide (Table I). Amino acid sequence confirmation was performed by examining the amino acid composition of peptic peptides derived from $\mathrm{D} \alpha \mathrm{T}$ 22 (Fig. 5 and Table VI).

Peptide DaT 23. Since the yield of DaT 23 purified from Ile-chain was very low $(1 \%)$, it was impossible to perform Edman degradation directly on this peptide. Therefore the 


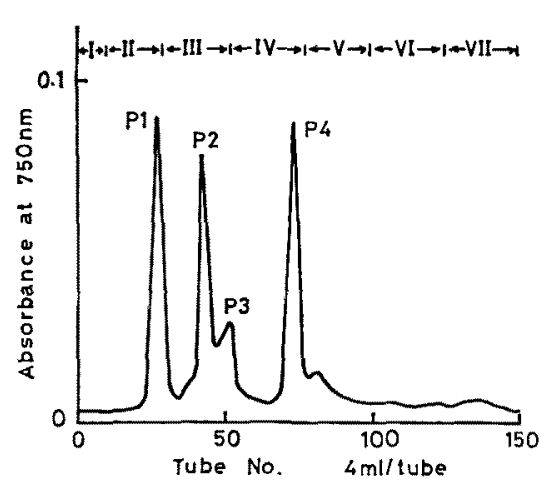

FIG. 5. Elution Profile of the Peptic Peptides Derived from DaT22 on a Column $(1.0 \times 48 \mathrm{~cm})$ of Dowex $1 \times 2$.

Buffer system (see ref. 1).

Table VI. Amino Acid Composition of Peptic Peptides Derived FROM DaT-22

\begin{tabular}{ccl}
\hline $\begin{array}{c}\text { Peptide } \\
\text { (DaT-22-) }\end{array} \begin{array}{c}\text { Position } \\
\text { in the } \\
\text { sequence }\end{array}$ & \multicolumn{1}{c}{ Amino acid composition } \\
\hline P1 & $25 \sim 29$ & $\mathrm{Arg}_{1.0(1)} \mathrm{Gly}_{1.0(1)} \mathrm{Val}_{1.1(2)} \mathrm{Tyr}_{1.3(1)}$ \\
P2-1 & $13 \sim 15$ & $\mathrm{Thr}_{1.0(1)} \mathrm{Ser}_{0.8(1)} \mathrm{Val}_{1.0(1)}$ \\
P2-2 & $16 \sim 20$ & $\mathrm{Ser}_{0.0(1)} \mathrm{Ala}_{1.4(1)} \mathrm{Val}_{0.7(1)} \mathrm{Leu}_{2.0(2)}$ \\
P3 & $1 \sim 3$ & $\mathrm{Ile}_{0.0(1)} \mathrm{Leu}_{1.0(1)} \mathrm{Phe}_{0.8(1)}$ \\
P4 & $6 \sim 14$ & $\mathrm{His}_{0.8(1)} \mathrm{Asp}_{1.0(1)} \mathrm{Glu}_{1.8(2)}$ \\
& & $\mathrm{Ala}_{0.8(1)} \mathrm{Val}_{1.0(1)} \mathrm{Leu}_{2.0(2)}$ \\
\hline
\end{tabular}

peptide CB II-TP was used to establish the amino acid sequence of $D \alpha T 23$, because CB II-TP is the amino terminal peptide of DaT 23. Conventional Edman degradation determined the N-terminal eight sequence of the peptide: Asp-Gly-Ser-Lys-Phe-Ser-Val-Tyr-. No further degradation was succeeded. Because of its highly hydrophobic properties, the peptide might be extracted into organic solvents during each step of Edman degradation. To minimize extraction losses, solid-phase Edman degradation was employed. After removal of $\mathrm{N}$ terminal Asp-Gly-Ser-Lys peptide by tryptic digestion, the remaining $C$-terminal peptide was attached to insoluble resin. Ten steps of Edman degradtion established the amino acid sequence to be: Phe-Ser-Val-Tyr-AspVal-Ser-Ile-Leu-. Peptic digestion of CB II-TP released a C-terminal peptide, of which amino acid composition was: $\operatorname{Pro}_{0.81(1)} \mathrm{Ala}_{1,00(1)}$
$\mathrm{Ile}_{2.26(2)} \mathrm{Leu}_{1.01(1)} \mathrm{Hse}_{(1)}$. Amino acid sequence of this peptide was also determined, by solidphase Edman degradtion, to be: Leu-ProIle-Ile-Ala-Hse. The complete amino acid sequence of DaT 23, deduced from this and previous studies, ${ }^{2)}$ is given in Table $\mathbf{I}$.

\section{DISCUSSION}

Amino acid sequences of nine tryptic peptides derived from performic acid oxidized lle-chain and cyanogen bromide fragments of Ile-chain have been determined. Together with the amino acid sequences of tryptic peptides reported in our previous paper, ${ }^{1)}$ amino acid sequences of 23 tryptic peptides, which were expected to be obtained from Ile-chain, have been established.

In earlier stage of this study, we have used a manual Edman degradation procedure described by Iwanaga and Samejima. ${ }^{7)}$ By their method, up to 12 amino acid sequence from $\mathrm{N}$-terminus of a peptide could be determined. Our modified Edman procedure allowed the determination of the sequence of 20 or more residues (see Table I). An important feature in the procedure employed here is that the extraction step of thiazolinones with ethylenedichloride. After single extraction, residual solvent was removed by aspiration. Then a small amount of TFA was added to make peptide adhering to the bottom of the tube. After quick removal of TFA, the second extraction was performed. Thus, the extraction losses of peptide could be reduced. Another reason for the successful Edman degradation of the peptides might be due to the presence of highly hydrophilic arginine residue at the $\mathrm{C}$ terminal end of tryptic peptides.

PTH-tryptophan was not identified directly on thin-layer chromatogram in amino acid sequence determination of $\mathrm{D \alpha T} 16$. As degradation proceeded further, the peptide became yellowish in color. This suggests that the repeated exposure to anhydrous acid may lead to some destruction of the indole ring of tryptophan.

Number of aspartic acid residues in peptide 
D $\alpha \mathrm{T} 20$ determined from the sequence studies ( 2 residues) was less than that from amino acid analysis ( 3 residues, see ref. 1 ). Although the reason for this discrepancy is obscure, the peptide DaT 20 might be contaminated by a small amount of peptide DaT 18, which contains 6 aspartic acid residues and has similar properties.

It has been observed that asparaginylglycyl bond tends to arrange from an $\alpha$ - to a $\beta$-peptide linkage during acid cleavage step of Edman degradation and the degradation results in rapidly decreasing yield of PTH-amino acid. ${ }^{13 \sim 15)}$ We have encountered a trouble in the degradation of peptides D $\alpha \mathrm{T} 20$ and D $\alpha \mathrm{T}$ 20-Cl using our Edman procedure. The yield of PTH-Asn at the 7th step in degradation of DoT 20 decreased to $40 \%$ to that at the 6 th step, thus further sequential degradation was unsuccessful. In the case of DaT $20-\mathrm{Cl}$, degradation has ceased completely at 7 th step. This trouble could be overcome by using the reaction condition of $40^{\circ} \mathrm{C}$ for $20 \mathrm{~min}$ for the cleavage step. Hence, it would be better to employ a milder condition, $40^{\circ} \mathrm{C}$ for $20 \mathrm{~min}$ in place of $50^{\circ} \mathrm{C}$ for $10 \mathrm{~min}$, for the cleavage step of Edman degradation.

Amino acid composition of DaT 23 isolated from tryptic digest of oxidized Ile-chain was: $\operatorname{Arg}_{1.00(1)}$ Asp $_{0.90(1)} \operatorname{Ser}_{1.66(2)}$ Pro $_{1.13(1)}$ Ala $_{1.43(1)}$ $\mathrm{Val}_{2.88(3)}$ Met-O $_{0.78(1)} \mathrm{Ile}_{2.97(3)} \mathrm{Leu}_{2.34(2)} \mathrm{Tyr}_{1.85(2)}$ $\mathrm{Phe}_{0.95(1)}$. This supports the validity of amino acid composition of the peptide deduced from analyses of peptides derived from cyanogen bromide fragments. ${ }^{2}$

\section{REFERENCES}

1) G. Funatsu, S. Yoshitake and M. Funatsu, Agric. Biol. Chem., 41, 1225 (1977).

2) G. Funatsu, S. Yoshitake, M. Ide, M. Kimura and M. Funatsu, ibid., 42, 1253 (1978).

3) H. T. Keutmann and J. T. Potts, Jr., Anal. Biochem., 29, 175 (1969).

4) D. H. Spackman, W. H. Stein and S. Moor, Anal. Chem., 30, 1190 (1958).

5) I. Smith, Nature (London), 171, 43 (1953).

6) T.-Y. Liu and Y. H. Chang, J. Biol. Chem., 246, 2842 (1971).

7) S. Iwanaga and Y. Samejima, Tanpakushitsu Kakusan Koso, 15, 1037 (1970).

8) J. D. Peterson, S. Nehrlich, P. E. Oyer and D. F. Steiner, J. Biol. Chem., 247, 4866 (1972).

9) K. Narita, Kagaku To Seibutsu, 7, 670 (1969).

10) G. Rdseau and P. Pantel, J. Chromatogr., 44, 392 (1969).

11) M. J. Horn and R. A. Laursen, FEBS Lett., 36, 285 (1973).

12) A. Previero, J. Derancourt, M. A. ColettiPreviero and R. A. Laursen, ibid., 33, 135 (1973).

13) P. Bornstein and B. Balian, J. Biol. Chem., 245, 4854 (1970).

14) W. Konigsberg, "Methods in Enzymology," Vol. XXV, ed. by C. H.W. Hirs and S.N. Timasheff, Academic Press Inc., New York, N.Y., 1972, p. 330.

15) E. Kolb, J. I. Harris and J. Bridgen, Biochem. J., 137, 185 (1974). 